\title{
Letter to the Editor Re: Effect of food intake and ambient air pollution exposure on ankylosing spondylitis disease activity
}

\author{
Srivani Punna, Judith Aniekwena ${ }^{*}$ D, Valery Effoe, Taiwo Ajose and Nicolas Bakinde
}

\section{Dear Editor,}

BioMed Central, Advances in Rheumatology.

We read with great interest the article "Effect of food intake and ambient air pollution exposure on ankylosing spondylitis disease activity" [1] by Narjes Soleimanifar et al. The authors touch on an important aspect of managing patients with ankylosing spondylitis (AS), especially given the increasing interest in the role of genetic, environmental and dietary factors in the pathogenesis and severity of disease. However, we would like the authors to clarify certain aspects of their work, which we strongly believe will be beneficial for the readership of Advances in Rheumatology.

The authors utilized a case-control study design to compare the effects of diet and ambient air pollution exposure on disease severity between patients with AS and healthy controls. We are curious to know why the authors chose this design as we think it is not the most appropriate study design to answer this question. It is challenging to know whether exposure or not (in this case diet and ambient air pollution) affects disease severity if the participants under investigation do not have the disease. From this study, it is unclear if the healthy controls would have experienced worsened disease activity as a natural progression if they were not exposed. We think a cohort design of patients with AS (retrospective or prospective) would have been more appropriate. As such, we think the conclusion drawn by the authors that living in areas with lower ambient pollution might be a solution for AS, is not supported by the available data.

The authors did not present any limitations to their study. Given the retrospective nature of case-control studies and their susceptibility to bias, specifically recall bias [2], it would be important for the readership of Advances in Rheumatology, if the authors provided more

* Correspondence: janiekwena@msm.edu

Department of Internal Medicine, Morehouse School of Medicine, Atlanta, GA, USA

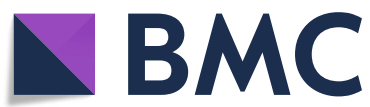

detail regarding how nutritional status was assessed. How reliable was the food-frequency questionnaire and how did they reduce the potential for recall bias?

In recent years, it has been suggested that certain foods with anti-inflammatory properties (such as the Mediterranean diet) could play a significant role in disease progression in patients with ankylosing spondylitis [3]. Sundstrom B et al. were able to demonstrate a positive correlation between arachidonic acid in plasma phospholipids and AS disease activity [4]. Relationship between exposure to environmental metals (thereby possibly air pollution) and spinal mobility in AS has also been demonstrated [5].

\section{Authors' contributions approved the final version. \\ Funding \\ Not applicable. \\ Availability of data and materials Not applicable.}

SP and JA wrote the initial draft of the letter. NB, VE and TA assisted in the preparation of the letter. All authors critically reviewed the letter and

Ethics approval and consent to participate Not applicable.

Consent for publication

Not applicable.

Competing interests

None declared.

Received: 13 March 2019 Accepted: 5 June 2019

Published online: 17 June 2019

References

1. Narjes Soleimanifar, Mohammad Hossein Nicknam, Katayoon Bidad et al Effect of food intake and ambient air pollution exposure on ankylosing spondylitis disease activity. Advances in Rheumatology 2019;59:9.

2. Sutton-Tyrrell K. Assessing bias in case-control studies. Proper selection of cases and controls. Stroke. 1991 Jul;22(7):938-42.

3. Kalogeropoulou AA. Nutritional aspects and vitamin D supplementation in ankylosing spondylitis. JRPMS. 2017;1(2):23-30. https://doi.org/10.22540/ JRPMS-01-023.

(c) The Author(s). 2019 Open Access This article is distributed under the terms of the Creative Commons Attribution 4.0 International License (http://creativecommons.org/licenses/by/4.0/), which permits unrestricted use, distribution, and reproduction in any medium, provided you give appropriate credit to the original author(s) and the source, provide a link to the Creative Commons license, and indicate if changes were made. The Creative Commons Public Domain Dedication waiver (http://creativecommons.org/publicdomain/zero/1.0/) applies to the data made available in this article, unless otherwise stated. 
4. B S, Johansson G, Kokkonen H, Cederholm T, Wållberg-Jonsson S. Plasma phospholipid fatty acid content is related to disease activity in ankylosing spondylitis. J Rheumatol. 2012 Feb;39(2):327-33. https://doi.org/10.3899/ jrheum.110575.

5. Shiue I. Relationship of environmental exposures and ankylosing spondylitis and spinal mobility: US NHAENS,2009-2010. Int J Environ Health Res. 2015; 25(3):322-9. https://doi.org/10.1080/09603123.2014.945512.

\section{Publisher's Note}

Springer Nature remains neutral with regard to jurisdictional claims in published maps and institutional affiliations.

Ready to submit your research? Choose BMC and benefit from:

- fast, convenient online submission

- thorough peer review by experienced researchers in your field

- rapid publication on acceptance

- support for research data, including large and complex data types

- gold Open Access which fosters wider collaboration and increased citations

- maximum visibility for your research: over $100 \mathrm{M}$ website views per year

At $B M C$, research is always in progress.

Learn more biomedcentral.com/submissions 